\title{
Protective Role of Some Natural Products on Phthalate-Induced Testicular Toxicity in Offspring Mice
}

\author{
L.Z. Habbak ${ }^{a}$, A.A. Khidr ${ }^{a}$, H.L. El-Gammal ${ }^{a}$, R.A. Masoud ${ }^{b}$ \\ ${ }^{a}$ Zoology Department, Damietta Faculty of Science, Damietta University, Egypt \\ ${ }^{b}$ Zoology Department, Faculty of Science, Sebha University, Libya
}

Received: 26 February 2013 / Accepted: 01 April 2013

*Corresponding author (email: reemashtwi@yahoo.com)

\begin{abstract}
Phthalates are wide spread environmental contaminants found in many household and consumer products. Many household products release phthalates that may pose unique challenges to human health, especially women and their children's. Phthalates have greater potential toxicity to mammals in general, reproductive and developmental toxicity in particular. The present study was designed to investigate the protective effect of some natural products (honeybee \& vitamin C) on testes development of offspring males. Gavage administration of $500 \mathrm{mg}$ Di-(2-ethylhexyl) phthalates (DEHP) $\mathrm{kg}^{-1}$ day $^{-1}$ to nursing mice form the $1^{\text {st }}$ to $21^{\text {st }}$ day after delivery induced massive alterations (degeneration and necrosis of some germ cells, in addition to absence of sperms) in the testes of their lactating offspring males. Ultrastructural examination of the $8^{\text {th }}$ week old offspring testes revealed karyolysis of germ cells, abnormal Leydig cells having few lipid droplets, deformed Sertoli cells being detached from the thick and irregular basal lamina and abnormal spermatids. The concomitant administration of honeybee $(10 \%)$ in drinking water or injection with $200 \mathrm{mg}$ vitamin $\mathrm{C} \mathrm{kg}^{-1}$ day $^{-1}$ led to amelioration of these pathological alterations and enhanced development of the testes. The obtained data demonstrated a protective action of honeybee \& vitamin $\mathrm{C}$ against the effects of DEHP on testes development of offspring males. The effects of these natural products might be attributed to the anti-oxidative effect of vitamin $\mathrm{C}$ and honey.
\end{abstract}

Keywords: DEHP, Honeybee, Mice, Offspring, TEM, Testes, Vitamin C

\section{Introduction}

Di-(2-ethylhexyl) phthalate (DEHP) is the most abundant phthalate in the environment. It is considered as ubiquitous environmental contaminant and has been measured in outdoor and indoor air, water, sediment, and soil [1]. Phthalates are used as plasticizers in PVC, nonPVC materials and other plastics [2,3]. DEHP have various industrial applications including the manufacture of household products, lubricating oils, solvents, cosmetics, personal care products, food and beverage packaging [4], soft plastic childcare articles and toys [5,6]. Phthalates can comprise up to $80 \%$ of the soft PVC in medical devices.

In general, DEHP have greater potential toxicity on mammals, reproductive and developmental toxicity in particular. Reproductive toxicity in laboratory animals has been reported, although it has not been studied as extensively [7]. Evidence of DEHP reproductive toxicity in humans is less conclusive [8]. In fact, DEHP and/or its metabolite, mono-(2-ethylhexyl) 
phthalate (MEHP), have been detected in human cord blood and maternal plasma [9]. In addition, MEHP has been found in human breast milk [10] and in infant $[11,12]$. Fetuses and infants are the most sensitive populations to environmental chemicals [13] can be maternally exposed to DEHP at early life stages [14].

Honey is a natural sweet substance used as food source mainly. Authors reported that honey can exert several health-beneficial effects such as, hepatoprotective, reproductive $[15,16]$, antioxidant, antihypertensive, anti-fungal [17] and anti-inflammatory [18].

Vitamin $\mathrm{C}$ is a natural water-soluble vitamin that is needed for optimal cell, tissue, organ and body functions. It is essential to a healthy diet as well as being a highly effective antioxidant and an enzyme cofactor for the biosynthesis of many important biochemicals. It activates some enzymes which have important roles in protein, carbohydrate and fat metabolisms. It exerts positive effects on lipid and iron metabolism [19] and promotes immune function. Vitamin $\mathrm{C}$ is a co-factor of some enzymes such as dopamine- $\beta$ hydroxylase and collagen synthase which are essential for the life [20]. In addition, vitamin C plays an important role on the defense system against viral infection and the development of cancer. Furthermore, vitamin $\mathrm{C}$ prevented the entrance of $\mathrm{Ca}^{++}$formed as a result of oxidative stress, and by this mechanism prevented intracellular damage [21].

\section{Materials and Methods}

\section{Chemicals}

Di-(2-ethylhexyl) phthalate (S.D, fine chemicals limited, 315-317 T.V. industrial state, 248 worli road, Mumbai-30; India) was dissolved in corn oil prior to oral administration. Each DEHP dose was given at $200 \mu \mathrm{l}$ oil/mouse. Egyptian honey was daily prepared as $10 \%(\mathrm{w} / \mathrm{w})$ honey in drinking water. Vitamin $\mathrm{C}$ was obtained from $\mathrm{El}$ Nassr Pharmaceutical Chemicals Company, Abu Zaabal, Cairo, Egypt. It was daily prepared in suitable concentrations, so that each vitamin $\mathrm{C}$ dose was given at $200 \mu \mathrm{l}$ distilled water/mouse and injected subcutaneously.

\section{Experimental Design}

Swiss albino mice (CDI) were obtained from Biological Supply Program of Theodore
Bilharzias Institute, Cairo, Egypt. Mice were maintained in the animal house of Zoology Department, Faculty of Science, Damietta University. Free excess of standard diet was supplied and water was allowed ad-libitum. They were housed with good ventilation and a $12 \mathrm{~h}$ light and dark cycle and allowed 2 weeks for acclimatization. Females were mated in a special cage (1 male/4 females) overnight, pregnant females were separated and daily checked for the signs of delivery. Directly before delivery, each pregnant female was kept in a separate cage. After delivery, the nursing mothers were classified into 5 experimental groups (5 nursing mothers each):

1-Control group: in which nursing mice were kept as controls without treatment.

2-Corn oil-treated group: in which nursing mice were given one daily oral gavage of $200 \mu 1$ corn oil, for 21 days during lactation.

3-DEHP-treated group: in which nursing mice were given one daily oral gavage of $200 \mu 1$ corn oil, containing a dose of 500mg DEHP $\mathrm{kg}^{-1}$ body weight, for 21 days during lactation.

4-DEHP and honey-treated group: in which nursing mice were given one daily oral gavage of $200 \mu \mathrm{l}$ corn oil, containing a dose of $500 \mathrm{mg} \mathrm{DEHP} \mathrm{kg}^{-1}$ body weight, and provided with honey (10\%) in drinking water, for 21 days during lactation.

5-Phthalate and vitamin C-treated group: in which nursing mice were given one daily oral gavage of $200 \mu \mathrm{l}$ corn oil, containing a dose of $500 \mathrm{mg}$ DEHP $\mathrm{kg}^{-1}$ body weight, and injected subcutaneously with $200 \mathrm{mg}$ vitamin $\mathrm{C} \mathrm{kg}^{-1}$ body weight, for 21 days during lactation.

Offspring males of all nursing mice under investigation were daily weighted from the $1^{\text {st }}$ to the $8^{\text {th }}$ week after birth. Five offspring males of nursing mothers from each experimental group were sacrificed by the end of $1^{\text {st }}, 2^{\text {nd }}, 3^{\text {rd }}, 6^{\text {th }}$ and $8^{\text {th }}$ weeks. The testes of each offspring male were removed, weighted and fixed in Boun's solution, washed, dehydrated, cleared, embedded in paraffin wax, sectioned at 5 micron thickness and stained using routine haematoxylin and eosin procedure [22]. Histopathological examination of the testis was carried out and photographed in Zoology department, Faculty of Science, Damietta University under a light microscope (Carl Ziess Jena Med 2 microscope equipped with camera).

The testis of the $8^{\text {th }}$ week old offspring was fixed in $2.5 \%$ glutaraldehyde in $0.1 \mathrm{M}$ sodium 
cacodylate buffer at $\mathrm{pH} 7.2$ for $3 \mathrm{~h}$ at room temperature. After rinsing in phosphate buffer the specimens were post fixed in $1 \%$ buffered osmium tetroxide at $\mathrm{pH} 7.2$ for $3 \mathrm{~h}$ at $4^{\circ} \mathrm{C}$. They were then dehydrated and embedded in araldite [23]. The araldite testes blocks were sectioned, examined and photographed using JEOL transmission electron microscope at Lab Unit, Zoology department, Faculty of Science, Alexandria University.

\section{Statistical analysis}

Data of each parameter of all experimental groups were tabulated as mean \pm S.D. The results were analyzed using SPSS program software (version 17.0). Student-t-test was used for the calculation of probability (p) taking in consideration the control results as basal value. Statements of significance are based on probability (p) levels of $\leq 0.05$ was considered statistically significant.

\section{Results}

The present study indicated that exposure of nursing mice to DEHP during lactation, had induced a significant decrease in the body weight of their offspring males at the end of lactation period ( $3^{\text {rd }}$ week of treatment). This decrease extended for weeks after lactation period. Addition of honey to the drinking water or injection of vitamin $\mathrm{C}$ into nursing mice induced an increase in the body weight of their offspring males (Table 1).

The present results also indicate that exposure of nursing mice to DEHP during lactation, caused deleterious effects in the testes of their offspring males. These effects were manifested by a decrease in orchidosomatic index and retardation in postnatal development of the testes (Table 2 and Fig. 1).

Although the direct exposure of offspring males to DEHP or its metabolites through their mother's milk has ended, by the end of lactation period (3weeks), the effect of their mothers exposure to DEHP during lactation, had extended to the $6^{\text {th }}$ week (Plate 4) and $8^{\text {th }}$ week old offspring testes (Plate 5). This extended effect expressed itself through decreased numbers of germ cells (due to death of some spermatogonia and spermatocytes), leading to dilatation in intercellular spaces and lumina of some seminiferous tubules, and the appearance of other disarranged or atrophied tubules, in addition to the absence of spermatozoa especially from the $8^{\text {th }}$ week old offspring testes.

Table 1. The changes in the body weight of offspring males of nursing mice exposed during lactation to DEHP and provided with honey or vitamin $\mathrm{C}$

\begin{tabular}{|c|c|c|c|c|c|c|c|c|c|}
\hline & \multicolumn{9}{|c|}{ Body weight (g) } \\
\hline & \multirow{2}{*}{$\begin{array}{l}\text { Control } \\
\text { mean } \pm \text { SD }\end{array}$} & \multicolumn{2}{|c|}{ Oil } & \multicolumn{2}{|c|}{ DEHP } & \multicolumn{2}{|c|}{$\mathrm{DEHP}+\mathrm{H}$} & \multicolumn{2}{|c|}{$\mathrm{DEHP}+\mathrm{V}$} \\
\hline & & mean $\pm \mathrm{SD}$ & $\mathrm{P}$ value & mean \pm SD & $\mathrm{P}$ value & mean $\pm \mathrm{SD}$ & $\mathrm{P}$ value & mean $\pm \mathrm{SD}$ & $\mathrm{P}$ value \\
\hline $1^{\text {st }}$ week & $2.41 \pm 0.7$ & $2.32 \pm 0.6$ & 0.10 & $2.22 \pm 0.6$ & 0.2 & $2.31 \pm 0.7$ & 0.61 & $2.42 \pm 0.7$ & 0.82 \\
\hline $2^{\text {nd }}$ week & $5.87 \pm 1.2$ & $5.77 \pm 1.1$ & 0.53 & $5.47 \pm 0.8$ & 0.10 & $5.68 \pm 1.0$ & 0.08 & $5.46 \pm 1.0$ & 0.11 \\
\hline $3^{\text {rd }}$ week & $10.04 \pm 1.4$ & $9.85 \pm 1.3$ & 0.41 & $7.40 \pm 0.93$ & $0.001 *$ & $9.71 \pm 0.9$ & 0.23 & $9.64 \pm 1.06$ & 0.11 \\
\hline $4^{\text {th }}$ week & $11.29 \pm 0.9$ & $11.28 \pm 0.3$ & 0.75 & $11.23 \pm 0.8$ & 0.84 & $11.24 \pm 0.7$ & 0.91 & $11.3 \pm 0.3$ & 0.90 \\
\hline $5^{\text {th }}$ week & $13.71 \pm 0.5$ & $14.20 \pm 0.3$ & 0.15 & $13.75 \pm 0.6$ & 0.21 & $13.75 \pm 0.5$ & 0.91 & $13.65 \pm 0.5$ & 0.90 \\
\hline $6^{\text {th }}$ week & $15.52 \pm 0.6$ & $15.61 \pm 0.7$ & 0.15 & $15.37 \pm 0.7$ & 0.69 & $15.65 \pm 0.5$ & 0.18 & $15.42 \pm 0.5$ & 0.72 \\
\hline $7^{\text {th }}$ week & $17.91 \pm 0.7$ & $18.24 \pm 0.7$ & 0.20 & $18.02 \pm 1.1$ & 0.75 & $18.15 \pm 0.9$ & 0.67 & $18.45 \pm 0.5$ & 0.12 \\
\hline $8^{\text {th }}$ week & $21.58 \pm 1.1$ & $23.04 \pm 0.7$ & 0.09 & $21.55 \pm 1.4$ & 0.97 & $21.55 \pm 1.4$ & 0.97 & $23.22 \pm 1.1$ & 0.14 \\
\hline
\end{tabular}

Each value represented the mean $\pm \mathrm{SD}$.

$*$ indicates a significant change at $\mathrm{p}<0.05$.

Control group: offspring males of nursing mice non-treated during lactation.

Oil-treated group: offspring males of nursing mice receiving an oral gavage of $200 \mu 1$ corn oil day ${ }^{-1}$ for 21 days.

DEPH-treated group: offspring males of nursing mice receiving $500 \mathrm{mg}$ DEHP kg-1 $\mathrm{day}^{-1}$ for 21 days.

$\mathrm{DEPH}+\mathrm{H}$-treated group: offspring males of nursing mice receiving $500 \mathrm{mg} \mathrm{DEHP} \mathrm{kg}{ }^{-1} \mathrm{day}^{-1}$ and fed on (10\%) honey for 21 days.

$\mathrm{DEPH}+\mathrm{V}$-treated group: offspring males of nursing mice receiving $500 \mathrm{mg}$ DEHP and $200 \mathrm{mg}$ vitamin $\mathrm{C} \mathrm{kg}^{-1} \mathrm{day}^{-}$ ${ }^{1}$ for 21 days. 
Table 2. The changes in the Orchidosomatic index of offspring males of nursing mice exposed during lactation to DEHP or TCE, and provided with honey or vitamin C

\begin{tabular}{|c|c|c|c|c|c|c|c|c|c|c|}
\hline & \multicolumn{10}{|c|}{ Orchidosomatic index } \\
\hline & \multicolumn{2}{|l|}{$1^{\text {st }}$ week } & \multicolumn{2}{|l|}{$2^{\text {nd }}$ week } & \multicolumn{2}{|l|}{$3^{\text {rd }}$ week } & \multicolumn{2}{|l|}{$6^{\text {th }}$ week } & \multicolumn{2}{|c|}{$8^{\text {th }}$ week } \\
\hline & $\begin{array}{l}\text { mean } \\
\pm \mathrm{SD}\end{array}$ & $\begin{array}{l}\mathrm{P} \\
\text { value }\end{array}$ & $\begin{array}{l}\text { mean } \\
\pm \mathrm{SD}\end{array}$ & $\begin{array}{l}\mathrm{P} \\
\text { value }\end{array}$ & $\begin{array}{l}\text { mean } \\
\pm \mathrm{SD}\end{array}$ & $\begin{array}{l}\mathrm{P} \\
\text { value }\end{array}$ & $\begin{array}{l}\text { mean } \\
\pm \text { SD }\end{array}$ & $\begin{array}{l}\mathrm{P} \\
\text { value }\end{array}$ & $\begin{array}{l}\text { mean } \\
\pm \mathrm{SD}\end{array}$ & $\begin{array}{l}\mathrm{P} \\
\text { value }\end{array}$ \\
\hline Control & $0.054 \pm 0.02$ & --- & $0.056 \pm 0.004$ & --- & $0.067 \pm 0.01$ & --- & $0.33 \pm 0.1$ & --- & $0.38 \pm 0.1$ & --- \\
\hline Oil & $0.024 \pm 0.00$ & 0.16 & $0.054 \pm 0.001$ & 0.45 & $0.065 \pm 0.002$ & 0.21 & $0.32 \pm 0.01$ & 0.16 & $0.37 \pm 0.07$ & 0.31 \\
\hline DEHP & $0.052 \pm 0.02$ & 0.20 & $0.055 \pm 0.003$ & 0.52 & $0.065 \pm 0.002$ & 0.21 & $0.175 \pm 0.08$ & $0.01 *$ & $0.22 \pm 0.09$ & $0.04 *$ \\
\hline $\mathrm{DEHP}+\mathrm{H}$ & $0.046 \pm 0.00$ & 0.07 & $0.056 \pm 0.002$ & 0.64 & $0.063 \pm 0.001$ & 0.12 & $0.31 \pm 0.06$ & 0.22 & $0.36 \pm 0.07$ & 0.2 \\
\hline $\mathrm{DEHP}+\mathrm{V}$ & $0.053 \pm 0.021$ & 0.25 & $0.054 \pm 0.001$ & 0.45 & $0.062 \pm 0.003$ & 0.14 & $0.34 \pm 0.2$ & 0.95 & $0.37 \pm 0.07$ & 0.31 \\
\hline
\end{tabular}

Each value represented the mean $\pm \mathrm{SD}$, * indicates a significant change at $\mathrm{p}<0.05$.

Control group: offspring males of nursing mice non-treated during lactation.

Oil- treated group: offspring males of nursing mice receiving an oral gavage of $200 \mu 1$ corn oil day $^{-1}$ for 21 days.

DEPH- treated group: offspring males of nursing mice receiving $500 \mathrm{mg}$ DEHP kg-1 day $^{-1}$ for 21 days.

$\mathrm{DEPH}+\mathrm{H}$-treated group: offspring males of nursing mice receiving $500 \mathrm{mg} \mathrm{DEHP} \mathrm{kg}{ }^{-1} \mathrm{day}^{-1}$ and fed on (10\%) honey for 21 days.

$\mathrm{DEPH}+\mathrm{V}$ - treated group: offspring males of nursing mice receiving $500 \mathrm{mg}$ DEHP and $200 \mathrm{mg}$ vitamin $\mathrm{C} \mathrm{kg}{ }^{-1}$ day $^{-1}$ for 21 days.

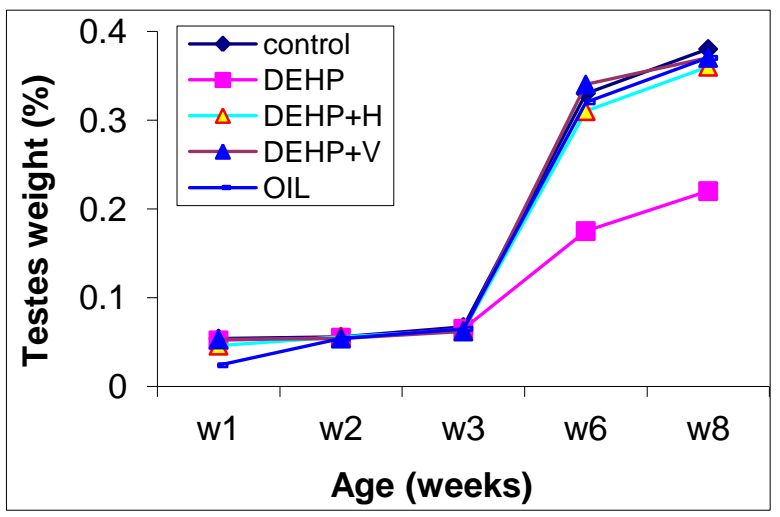

Fig. 1 The changes in the Orchidosomatic index of offspring males of nursing mice exposed during lactation to DEHP, and provided with honey or vitamin $\mathrm{C}$

Ultrastructural examination of the testes of the $8^{\text {th }}$ week old offspring males of non-treated nursing mice revealed normal arrangement of testicular tissue (Fig. 2). Seminiferous tubule is contained in basal lamina with myoid cells outside and possesses germ at various stages of spermatogenesis (Fig. 2) and Sertoli cells. In electron micrograph, spermatogonia (A) are characterized by large pale ovoid nuclei with their long axis parallel to the basal lamina and containing finely granular euchromatin and dense clumps of peripheral heterochromatin. Their granular cytoplasm is scantly with poor rough endoplasmic reticulum, ribosomes, spherical or ovoid mitochondria and the Golgi apparatus. Spermatogonia (B) are spherical in shape with rounded nuclei, electron dense nucleoplasmic matrix.

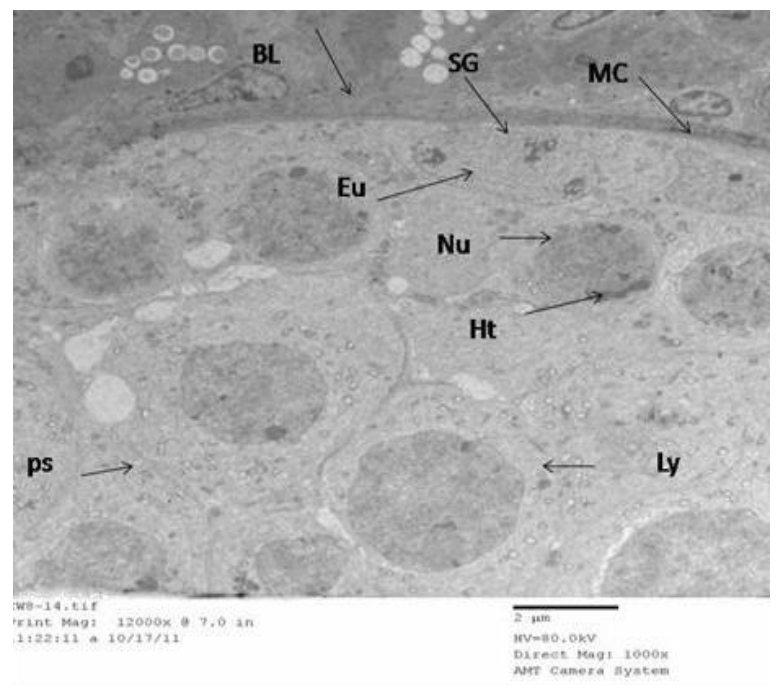

Fig. 2 Electron micrograph of the testes of the $8^{\text {th }}$ week old offspring males of non treated control nursing mice (mothers) revealing normal arrangement of testicular tissue. Seminiferous tubule is contained in thin basal lamina (BL) with myoid cells (MC) outside and consists of various stages of germ and Sertoli cells. Spermatogonia (SG) are oval or rounded in shape possessing mitochondria (M) in their cytoplasm and nuclei containing nucleoli $(\mathrm{Nu})$, euchromatin (Eu) and dense clumps of peripheral heterochromatin (Ht). Pimary spermatocytes (PS) are rounded in shape with large rounded nuclei and nucleoli having abundant amount of granular cytoplasm; characterized by dispersed oval mitochondria, cisternae of smooth endoplasmic reticulum and lysosomes (Ly). 
Their cytoplasmic organelles are similar to those in A-type. They are followed by primary spermatocytes, recognized by their spherical shape with abundant granular cytoplasm, characterized by dispersed mitochondria, cisternae of smooth endoplasmic reticulum, lysosomes and Golgi apparatus.

There are large clusters of small rounded spermatids (Fig. 3), followed by elongated spermatids (Fig. 4). The normal rounded spermatids have rounded nuclei containing distinct nucleolus, with homogenous chromatin in which the formation of the acrosome, indicated by the presence of a pro-acrosomal granule, acrosomal cap, Golgi apparatus over the anterior hemisphere of the nucleus. The cytoplasm contains some mitochondria, few stacks of rough endoplasmic reticulum and lysosomes.

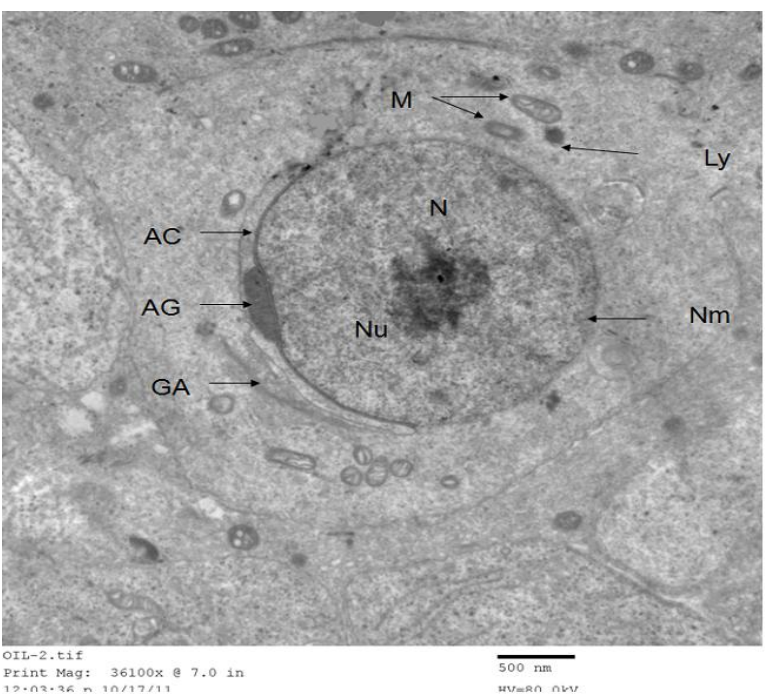

Fig. 3 Electron micrograph of the testes of the $8^{\text {th }}$ week old offspring males of non treated control nursing mice (mothers) showimg normal rounded spermatid (RS) in which the formation of the acrosome, indicated by the presence of a proacrosomal granule (AG), acrosomal cap (AC), Golgi apparatus (GA) over the anterior hemisphere of the nucleus $(\mathrm{N})$ which is rounded in shape, containing distinct nucleolus $(\mathrm{Nu})$, homogenous chromatin materials and surrounded by nuclear membrane $(\mathrm{Nm})$. The cytoplasm contains mitochondria (M), few stacks of rough endoplasmic reticulum (RER) and lysosome (Ly).

Sertoli cells exhibit typical irregular nuclei and well-defined cytoplasm extending from the basal lamina of to the lumen, filling the narrow spaces between the germ cells (Fig. 5). The irregular nucleus and its prominent nucleolus are surrounded by a nuclear membrane with a characteristic indentation and contain a plentiful amount of euchromatin. The cytoplasm contains numerous mitochondria, few stacks of smooth and rough endoplasmic reticulum, polyribosomes, Golgi apparatus and lysosomes.

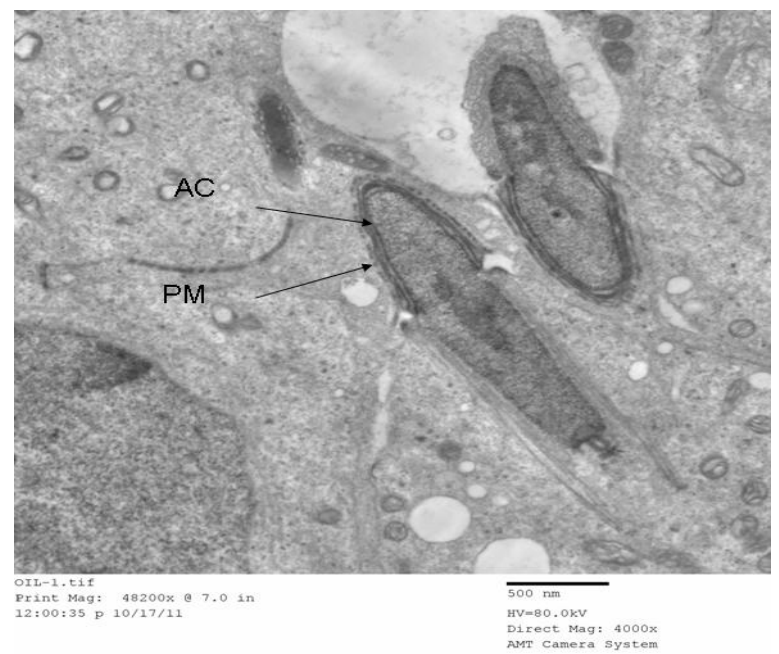

Fig. 4 Electron micrograph of the testes of the $8^{\text {th }}$ week old offspring males of non treated control nursing mice (mothers) showing normal elongated spermatid (ES) with its characteristic acrosomal cap (AC) surrounded by the plasma membrane (PM).

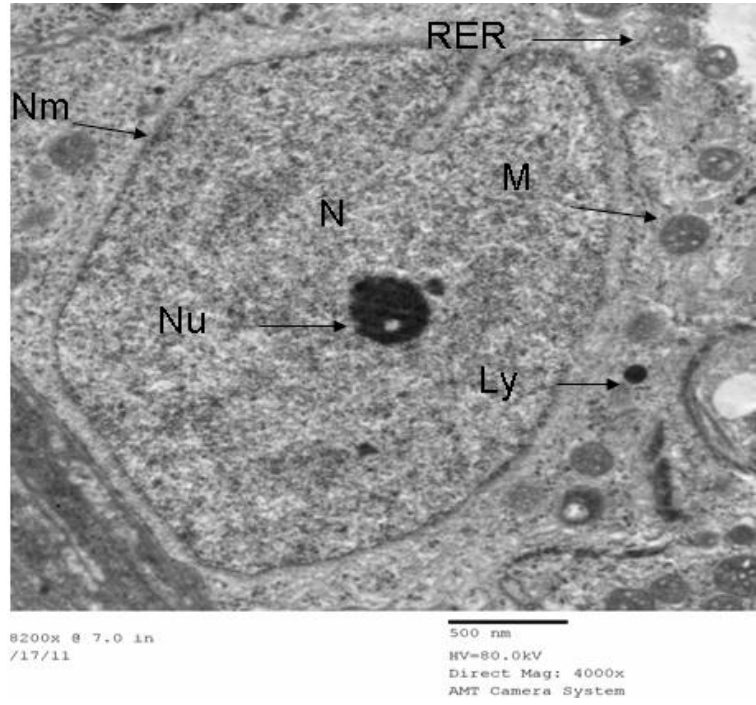

Fig. 5 Electron micrograph of testis of the $8^{\text {th }}$ week old offspring males of non treated control nursing mice (mothers) showing Sertoli cell characterized by its irregular nuclei and well-defined cytoplasm. The irregular nucleus and its prominent nucleolus $(\mathrm{Nu})$ are surrounded by a nuclear membrane $(\mathrm{Nm})$ with a characteristic indentation and contain a plentiful amount of euchromatin (Eu). The cytoplasm contains large number of polyribosomes, numerous mitochondria $(\mathrm{M})$, few stacks of smooth and rough endoplasmic reticulum (RER) and Golgi apparatus (GA), and lysosomes (Ly). 
The interstitial tissue between seminiferous tubules contains distinct Leydig cells, white blood cells and blood vessels (Fig. 6).
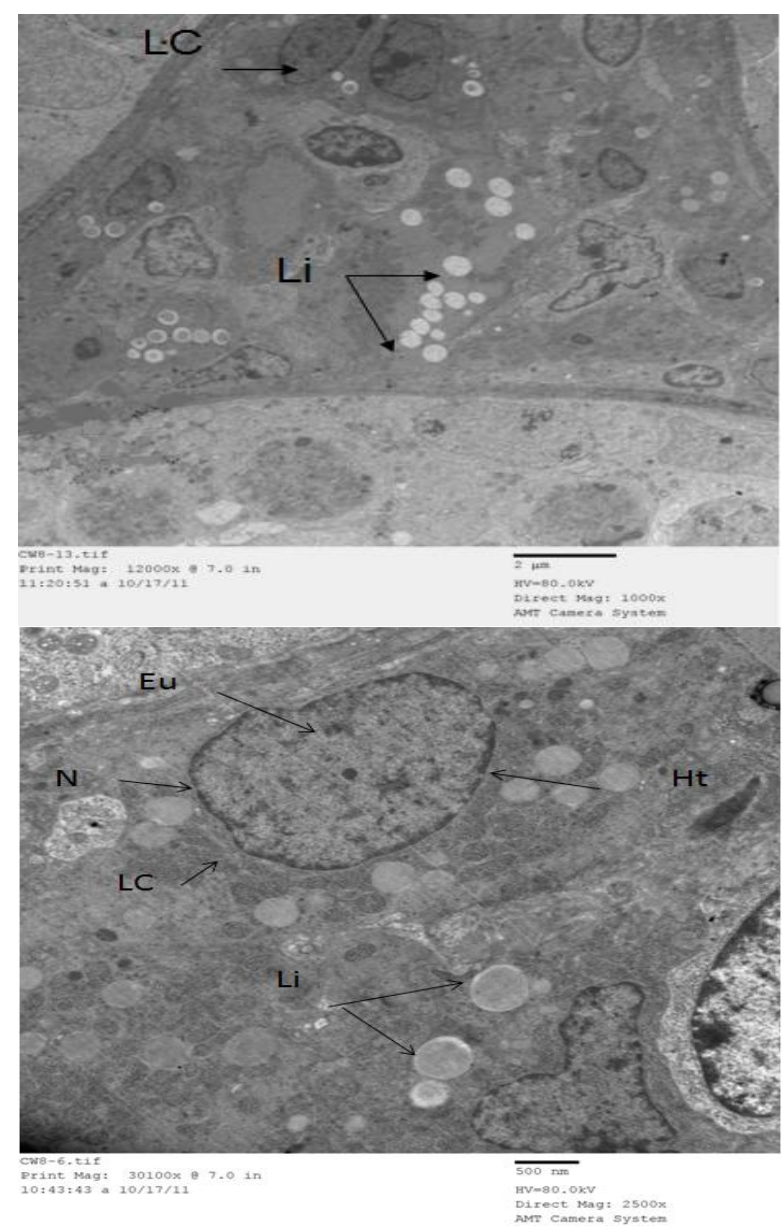

Fig. 6 Electron micrograph of testis of the $8^{\text {th }}$ week old offspring males of non treated control nursing mice (mothers) showing Leydig cells and white blood cells in testis interstitium. Leydig cell (LC) possesses large nuclei $(\mathrm{N})$ with euchromatin $(\mathrm{Eu})$ and coarse clumps of peripheral heterochromatin (Ht). Its cytoplasm contains large number of lipid droplets (Li), mitochondria and few stacks of smooth endoplasmic reticulum cisternae .Macrophages are the white blood cells found in the interstitial tissue, characterized by a large eccentrically placed nucleus and numerous small pseudopodia.

Leydig cells possess large nuclei with euchromatin and coarse clumps of peripheral heterochromatin. Its cytoplasm contains large number of lipid droplets, mitochondria and few stacks of smooth endoplasmic reticulum cisternae. Macrophages are the white blood cells found in the interstitial tissue, characterized by a large eccentrically placed nucleus and numerous small pseudopodia.

The seminiferous tubules of offspring males of nursing mice exposed to DEHP showed thick and irregular basal lamina and reduction in the germ cells leading to dilatation of intercellular spaces and lumen (Fig. 7). Degeneration and necrosis appeared in spermatogonia and primary spermatocytes characterized by karyolitic nucleus without nuclear membrane or nucleolus (Fig. 8) in addition to abnormal rounded and elongate spermatids (Fig. 9).

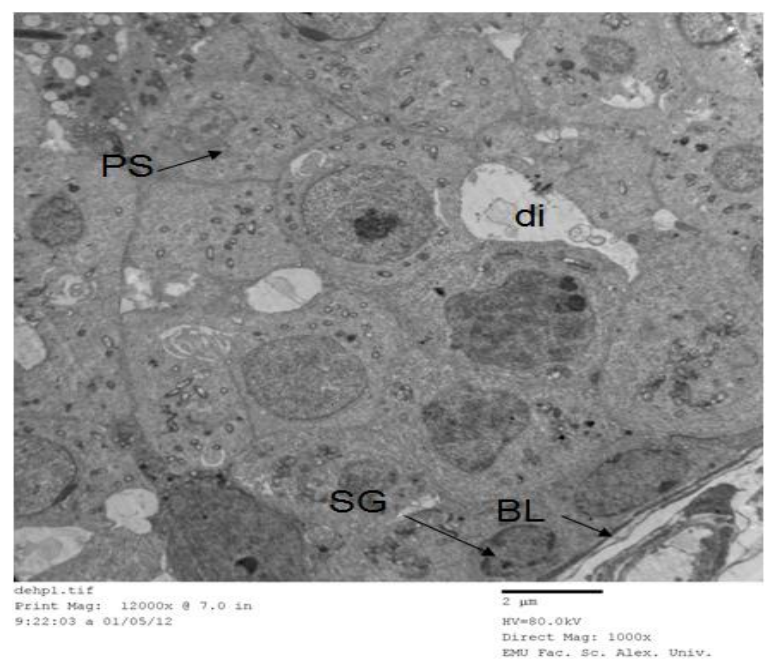

Fig. 7 Electron micrograph of testis of the $8^{\text {th }}$ week old offspring males treated of DEHP nursing mice (mothers) showing irregular thickening of the basal lamina (BL) of some seminiferous tubules and reduction in the germ cells leading to dilatation of intercellular spaces (di). Degeneration and necrosis appeared in spermatogonia (SG) and primary spermatocytes (PS) characterized by obviously atrophied nucleus without nuclear membrane or nucleolus reflecting a stage of karyolysis.

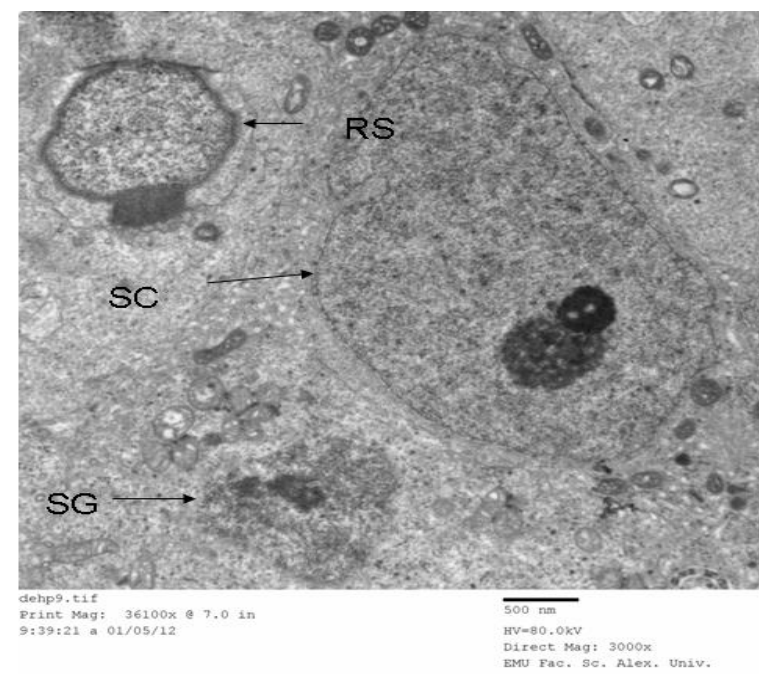

Fig. 8 Electron micrograph of testis of the $8^{\text {th }}$ week old offspring males treated of DEHP nursing mice (mothers) showing deformed Sertoli cells (SC), being detached from the irregular basal lamina and abnormal rounded spermatid (RS). 


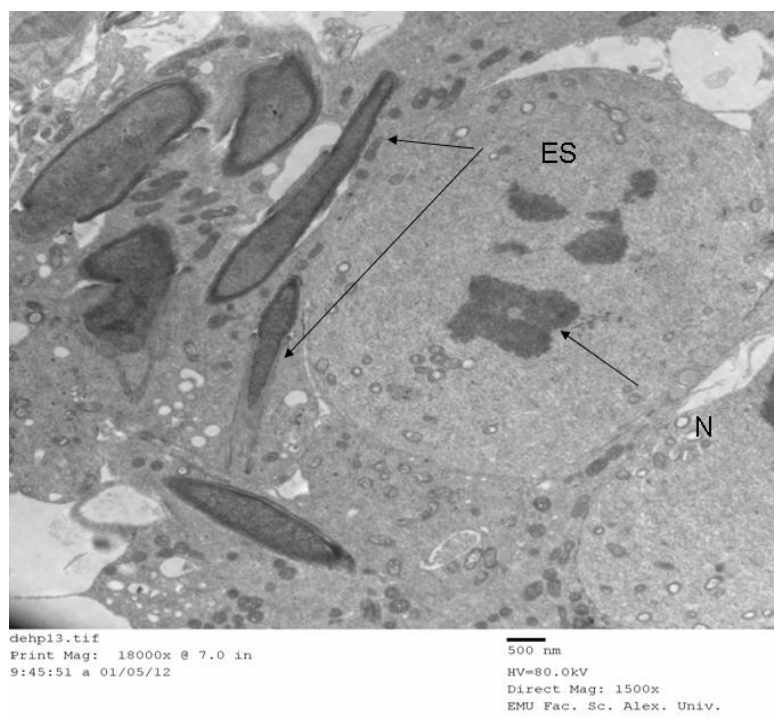

Fig. 9 Electron micrograph of the testis of the $8^{\text {th }}$ week old offspring males treated of DEHP nursing mice (mothers) showing abnormal elongate spermatids (ES) and primary spermatocytes characterized by obviously atrophied nucleus $(\mathrm{N})$ without nuclear membrane or nucleolus reflecting a stage of karyolysis.

Deformed Sertoli cells, being detached from the irregular basal lamina, abnormal nucleus surrounded by irregular nuclear membrane and increased heterochromatin (Fig. 9). The interstitial tissue showed abnormal Leydig cells with irregular nucleus, reduced smooth endoplasmic reticulum, few lipid droplets, and large number of mitochondria (Fig. 10).

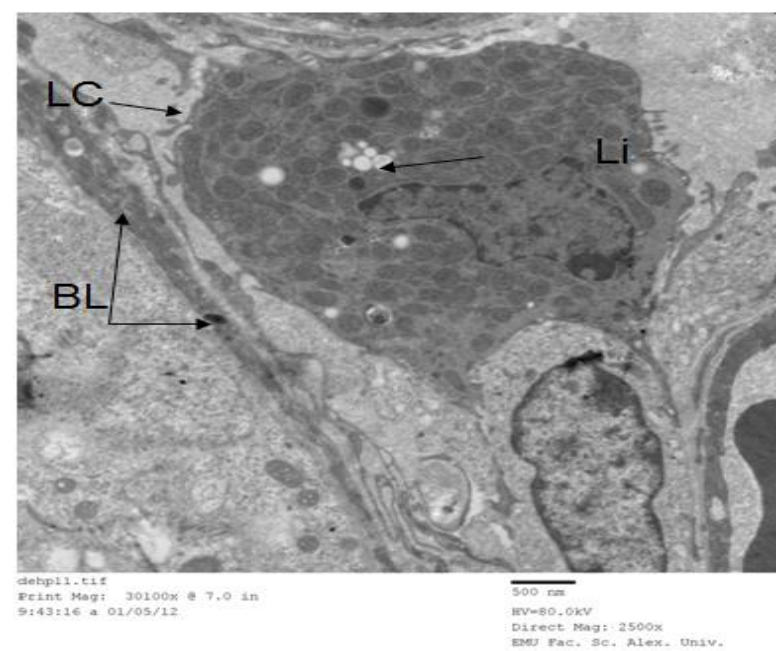

Fig. 10 Electron micrograph of testis of the $8^{\text {th }}$ week old offspring males treated of DEHP nursing mice (mothers) showing interstitial tissue with abnormal Leydig cells (LC) having irregular nucleus, reduced smooth endoplasmic reticulum, few lipid droplets (Li), and large number of vacuolated mitochondria (M) and thickening and irregulation of the basal lamina (BL).
The testes of offspring males of mothers treated with DEHP + honey (Fig. 11) or DEHP + vitamin C (Fig. 12) exhibited normal organization of testicular tissue with increased numbers of germ cells, smooth basal lamina, although the presence of some dilatation of intercellular spaces. Leydig cells appears normal with large number of lipid granules, although the presence of some dilatation in the interstitium.

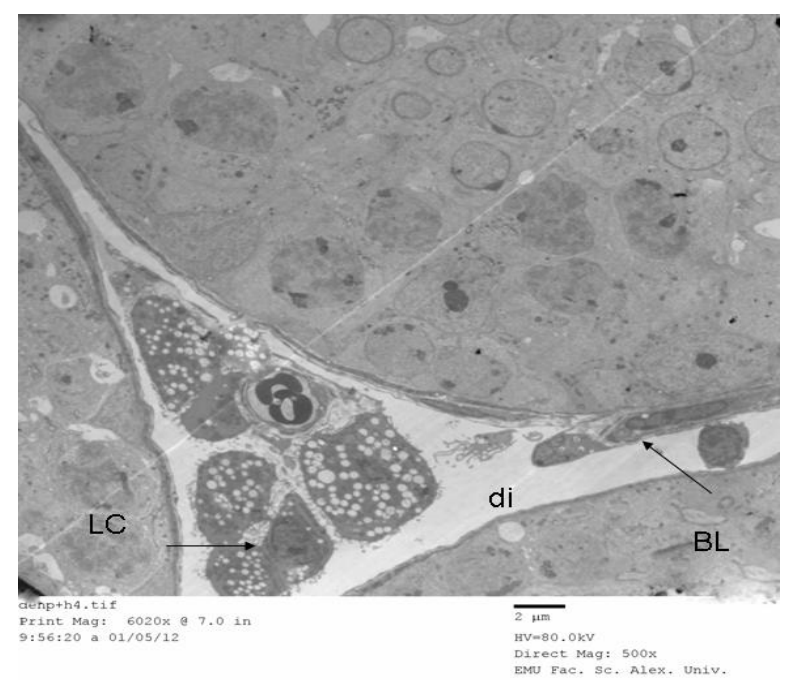

Fig. 11 Electron micrograph of the testes of the $8^{\text {th }}$ week old offspring males of treated with DEHP $+\mathrm{H}$ exhibiting normal organization of testicular tissue with increased numbers of germ cells, smooth basal lamina (BL), although the presence of some dilatation of intercellular spaces. Leydig cells appears (LC) normal with large number of lipid granules, although the presence of some dilatation in the interstitium (di).

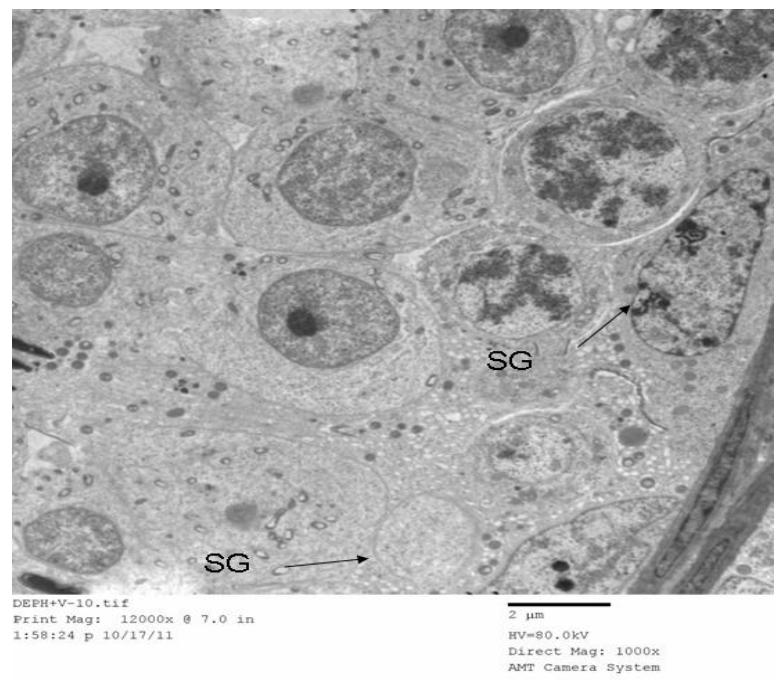

Fig. 12 Electron micrograph of the testes of the $8^{\text {th }}$ week old offspring males of treated with DEHP + vitamin $\mathrm{C}$ exhibiting normal organization of testicular tissue, although the presence of degeneration and necrosis of some germ cells of the seminiferous tubules. 


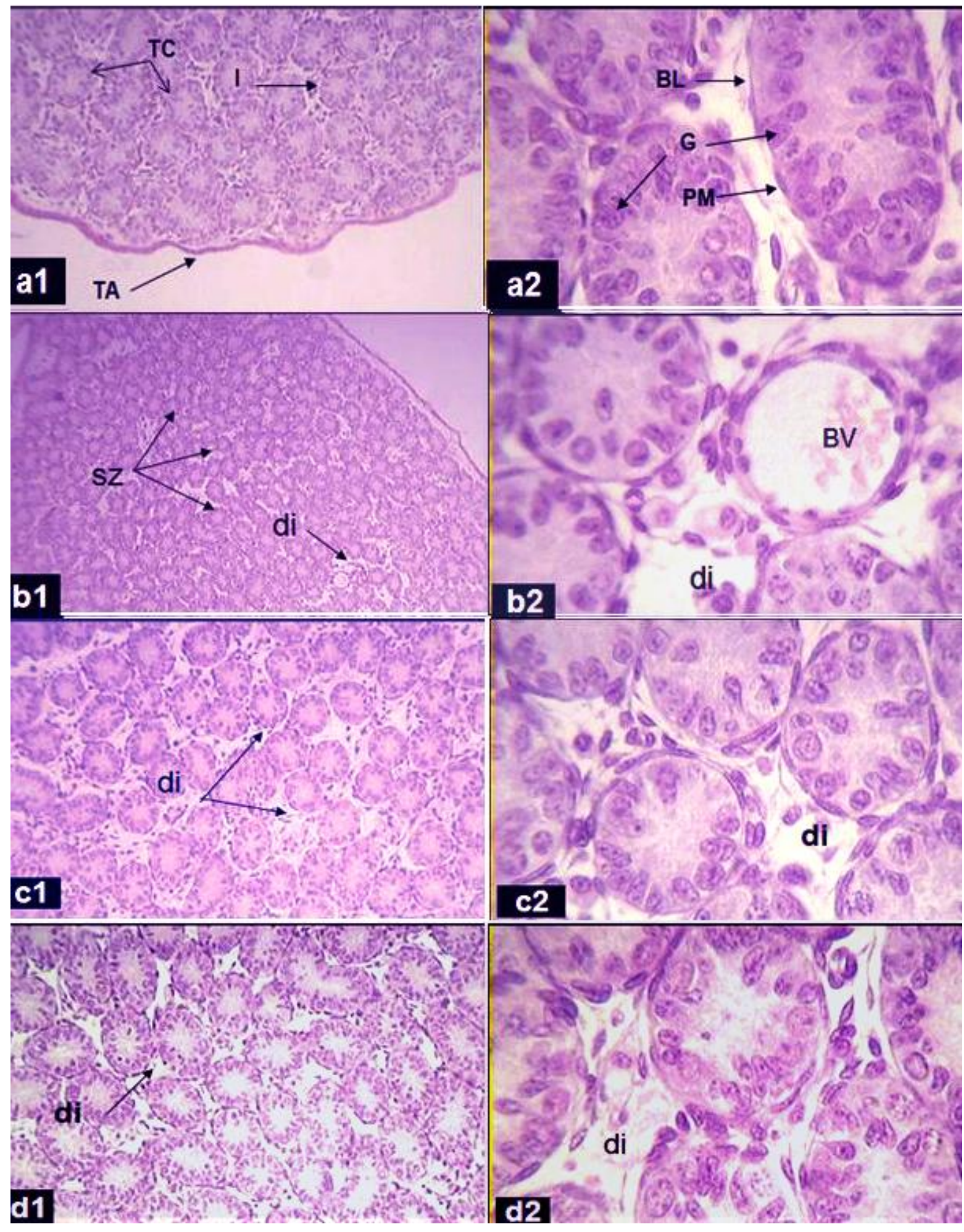

Plate 1. Photomicrographs of testis of the $1^{\text {st }}$ week old offspring males of nursing mice exposed during lactation to DEHP and provided with honey or vitamin C (H\&E, x 100 in plate 1.1 and x 400 in plate 1.2). Normal testes of the $1^{\text {st }}$ week old offspring males of the non-treated mothers (Plate 1a), appears as a group of testicular cords (TC) separated by interstitium (I) and encapsulated in tunica albuginea (TA). Each testicular cord, which later develops into seminiferous tubule, is a cellular aggregation of the primordial germinal cells, gonocytes $(\mathrm{G})$, the precursor of spermatogonial cells, fused with the coelomic epithelium-derived cells (the Sertoli cell precursors) and surrounded by a basal lamina (BL) with premyoid cells out side (PM). Leydig cells, white blood cells and blood vessels (BV) can be found in the interstitium 


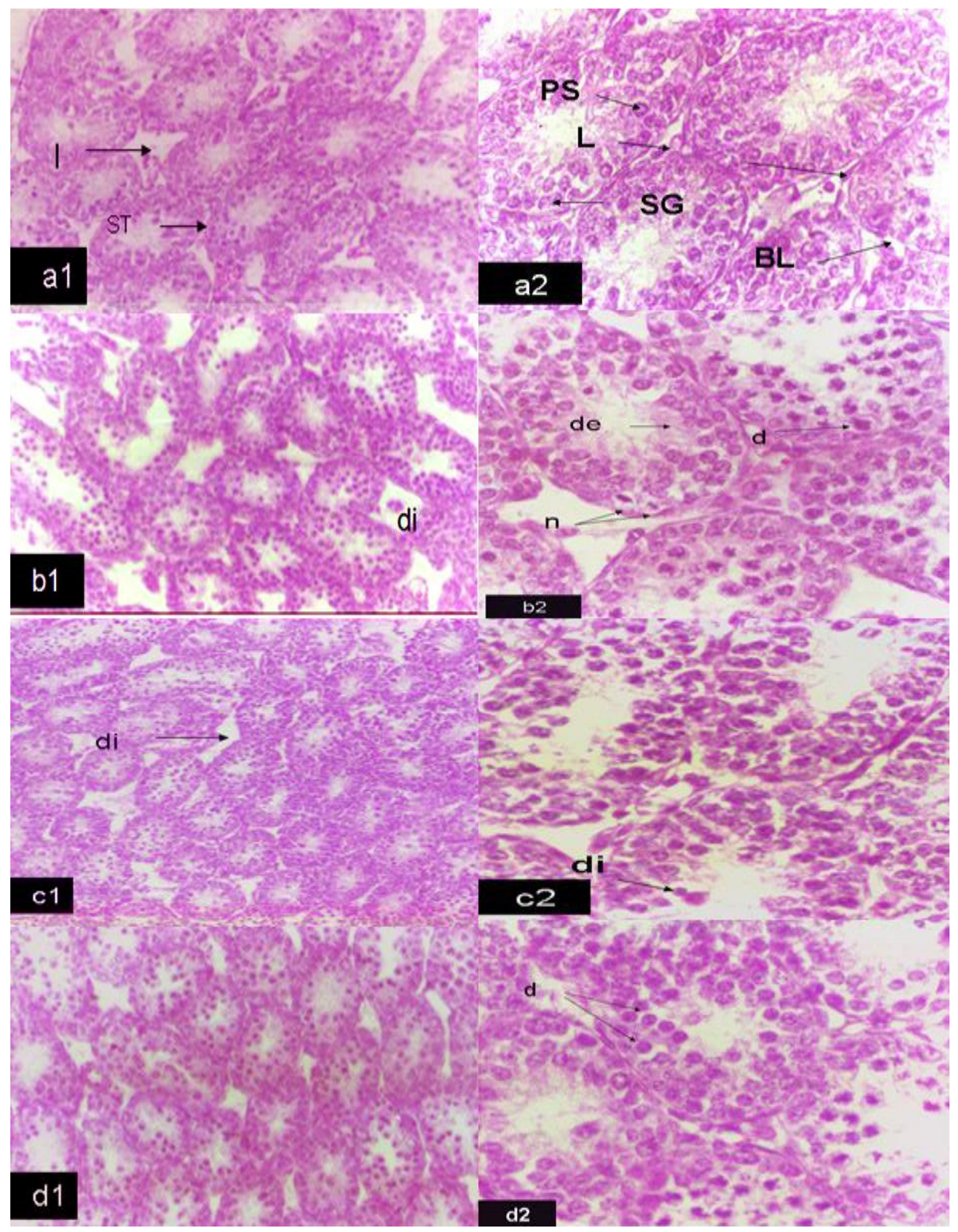

Plate 2. Photomicrographs of testis of the $2^{\text {nd }}$ week old offspring males of nursing mice exposed during lactation to DEHP and provided with honey or vitamin C (H\&E, x 200 in plate 2.1 and x 400 in plate 2.2). Normal testes of the $2^{\text {nd }}$ week old offspring males of the non-treated mothers (Plate 2a), appears as a group of seminiferous tubules (ST) separated by interstitium (I). Each seminiferous tubule is a cellular aggregation of germinal cells; spermatogonial cells (SG), giving rise to the first meiotic spermatocytes (SP) fused with Sertoli cells and surrounded by a basal lamina (BL) with premyoid cells (PM) out side. Leydig cells (L), white blood cells, and blood vessels can be found in the interstitium 


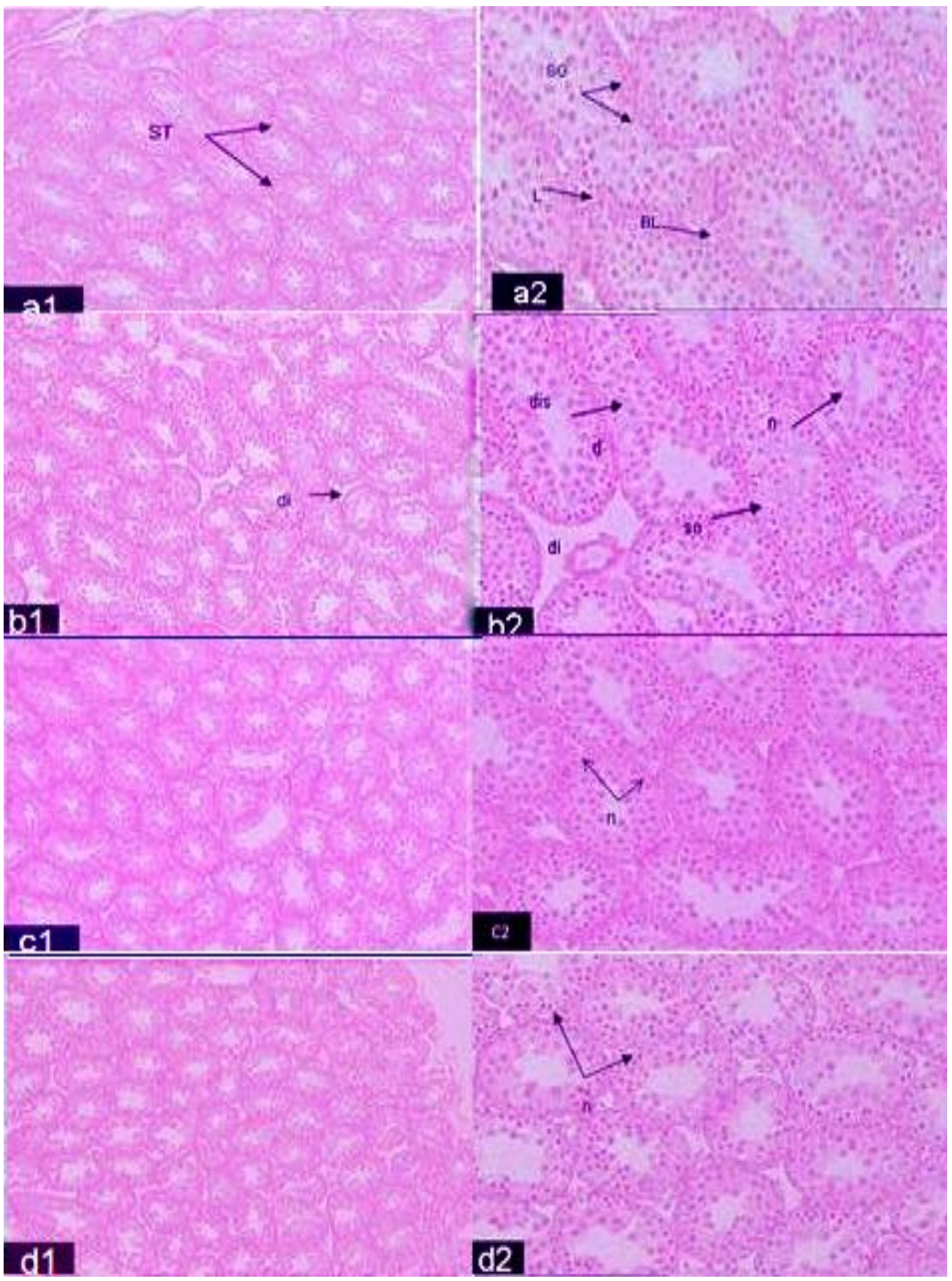

Plate 3. Photomicrographs of testis of the $3^{\text {rd }}$ week old offspring males of nursing mice exposed during lactation to DEHP and provided with honey or vitamin C (H\&E, x 100 in plate 3.1 and x 200 in plate 3.2). Normal testes of the $3^{\text {rd }}$ week old offspring males of the non-treated mothers (Plate 3a), appears as a group of seminiferous tubules (ST) separated by interstitium (I). The testis of the $3^{\text {rd }}$ week old offspring males differs from that of the $2^{\text {nd }}$ week in the appearance of the first formed rounded spermatids 


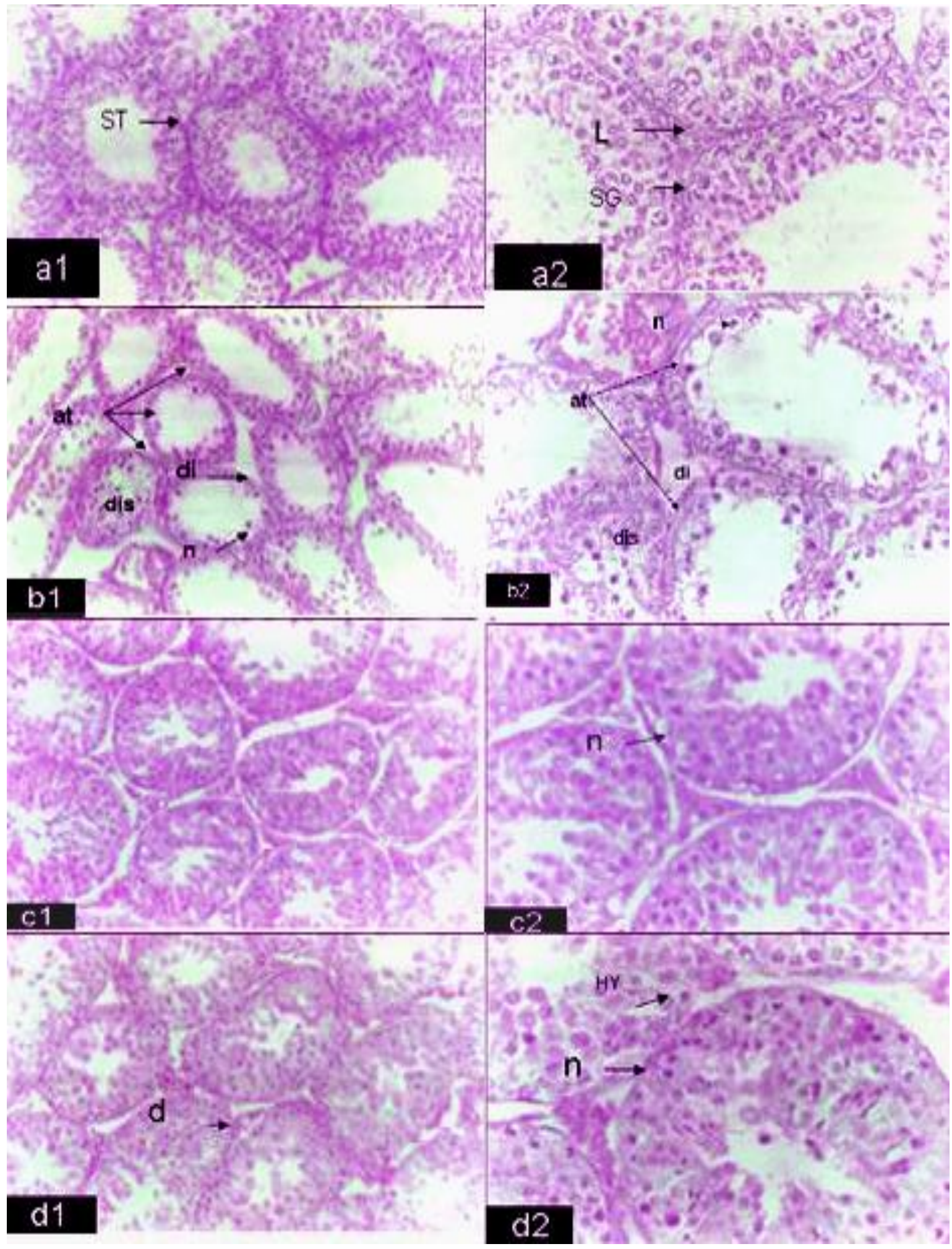

Plate 4. Photomicrographs of the testes of the $6^{\text {th }}$ week old offspring males of nursing mice exposed during lactation to DEHP and provided with honey or vitamin C (H\&E, x 200 in plate 4.1 and x 400 in plate 4.2). Plate 4a shows normal testis of the $6^{\text {th }}$ week old offspring males of non-treated nursing mothers with seminiferous tubules (ST) separated by interstitial tissue (I) containing distinct Leydig cells (L) and blood vessels. Each seminiferous tubule is surrounded by the basal lamina (BL) formed of myoid cells (M), and contains Sertoli cells (SC), spermatogonia (SG) and primary spermatocytes (PS) followed by rounded spermatids (RS) and elongated spermatids which undergo dramatic shape changes, forming spermatozoa 


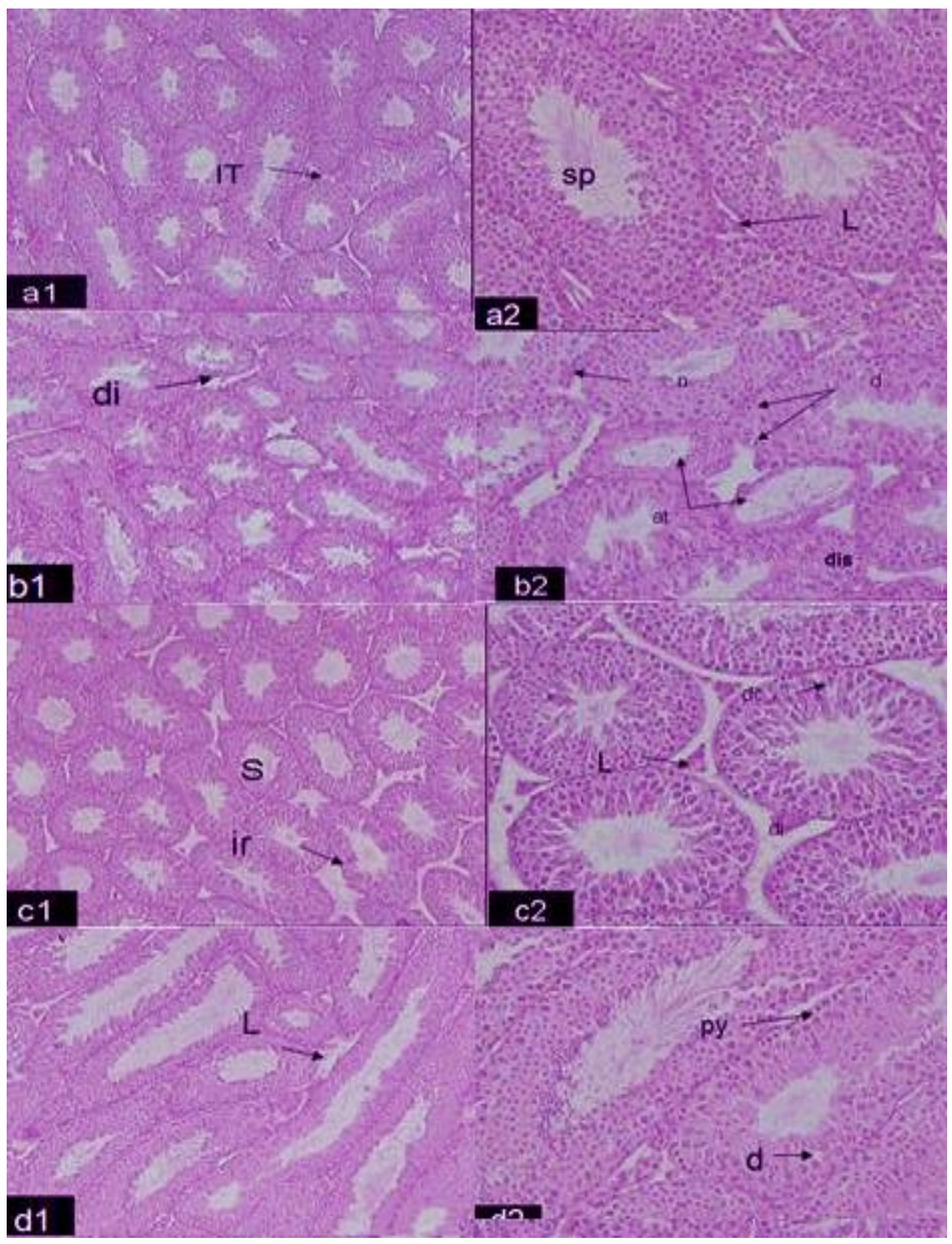

Plate 5. Photomicrographs of the testes of the $8^{\text {th }}$ week old offspring males of nursing mice exposed during lactation to DEHP and provided with honey or vitamin C (H\&E, x 200 in plate 5.1 and x 400 in plate 5.2). Plate 5 a shows normal testis of the $8^{\text {th }}$ week old offspring males of non-treated nursing mothers with seminiferous tubules (ST) separated by interstitial tissue (I) containing distinct Leydig cells (L) and blood vessels. Each seminiferous tubule is surrounded by the basal lamina (BL) and contains Sertoli cells (SC), spermatogonia (SG), primary spermatocytes (PS), rounded spermatids (RS) and elongated spermatids followed by spermatozoa (SP) within the lumen 


\section{Discussion}

Phthalates are widely spread environmental contaminants found in many household and consumer products. Since phthalates are not chemically bound to these products they can easily released into the environment [9] and may pose unique challenges to human health, especially to mothers and their offspring. Fetuses and infants, who are believed to be one of the most sensitive populations to environmental chemicals [13], can be maternally exposed to DEHP. Studies have shown that DEHP and/or their metabolites are capable of crossing form mother's body to their offspring through the placenta [9] or milk [10,14]. Exposure to DEHP during lactation can result in changes in milk quality and quantity and can lead to DEHP and MEHP exposure to the suckling pups [24].

The present study indicate that exposure of nursing mothers to DEHP during lactation had induced a significant decrease in orchidosomatic index and induced retardation in postnatal development of the testes of their offspring males. Our results are consistent with other studies in rodents in which oral exposure to DEHP causes deleterious effects in the male reproductive system. These effects include decreased weights of male reproductive organs [25-27], decreased or complete loss of spermatogenesis [28], and histopathological changes in the male reproductive organs especially the testes $[25,29,30]$.

The testis at early developmental stages (late gestation and early days after birth) is more sensitive to DEHP than that of adult animals $[29,41]$. Neonatal or young animals have been found to be more sensitive to the male reproductive effects of DEHP than adults [3234]. Studies have found that concurrent exposure to multiple DEHP can cause cumulative effects on the male reproductive system [35].

Testis appears to be the main target organs for DEHP toxicity whereas Sertoli cells and Leydig cells $[36,37]$ are the primary cellular targets of DEHP-induced toxicity. Characteristics of histopathological changes in the testis include disorganization of the seminiferous tubule, vacuolation of the cytoplasm, and destruction of intercellular specializations in Sertoli cells, followed by degeneration of spermatocytes by apoptosis and/or sloughing of germ cells into the lumen of seminiferous tubules $[27,30,38]$, seminiferous tubule and epididymal atrophy [25]. Our histopathological findings are very similar to these findings.

Maternal exposure to DEHP during fetal and/or neonatal periods may cause reproductive and developmental toxicities in offspring due to their actions as endocrine-disrupting chemicals $[7,34]$. Studies have examined the antiandrogenic effects in newborn males, such as reduced penile size, shorter anogenital distance, and cryptorchidism [36,37]. DEHP could cause dysfunction of the testis gubernaculum via its anti-androgen effect, dysplasia and dysfunction of Sertoli cells, Leydig cells and spermatogenic cells in fetal mice [24].

Barlow et al. [39] has indicated that a variety of steroido-genesis related genes were altered following DEHP- exposure indicating the potential mechanism for decreased testosterone synthesis. A similar genetic response was reported in fetal and prepubertal testes. DEHP have also been shown to decrease Leydig cell function $[9,40]$. Specific outcomes observed include a reduction in testosterone [41].

The mechanisms of the toxic effect of DEHP on the male reproductive system appear to be mediated by MEHP [40,41]. Also in the testis peroxisome proliferators-activated receptors (PPAR) and their subtypes are in focus to explain some of the reproductive effects of phthalates [9,42]. DEHP and MEHP exposure reduces expression of cell cycle regulators, Ccnd2 and Cdk4 leading to inhibition of cell prolifeation. Moreover, it has been reported that DEHP exposure resulted in oxidative stress causing male reproductive toxicity [43].

Oxidative stress is the condition when there are more free radicals in the body than antioxidants. Antioxidant is defined as any substance that when present at low concentrations with an oxidizable substrate delays or prevents oxidation of that substrate [44]. Studies have demonstrated the beneficial effects of antioxidants in preventing or ameliorating testicular damage in rats or mice [45].

Studies have investigated the in vivo antioxidant capacity of honey [44]. Honey has been shown to prevent lipid oxidation, it was more effective than $\alpha$-tocopherol and butylated hydroxytoluene, two commonly used phenolic antioxidants. Honey is known to be rich in both enzymatic and non-enzymatic antioxidants, including catalase, ascorbic acid, flavonoids and alkaloids. Flavonoids might be responsible for the protection of cells by scavenging radical activity including both superoxide and hydroxyl 
radicals. Reports indicate that flavonoids effectively prevent lipid peroxidation and protein oxidation [46].

Mohamed et al. [15] indicated that honey may protect or ameliorate induced testicular damage in rats via its antioxidant effect. He also reported that honey supplementation in normal rats improved spermatogenesis and reduced the level of lipid peroxidation reduced the toxic effects on spermatogenesis in rats [47]. Also, honey has been used in treating male subfertility, by increasing sperm count. Mahaneem et al. [47] also reported that ingestion of diluted honey by male rats induces enhancement in epididymal sperm count, spermatogenesis, increasing selectively relative weight of epididymis, and increasing sorbital dehydrogenase activity and reducing lactate dehydrogenase activity [48].

Vitamin $\mathrm{C}$ is protective against the testicular effects of DEHP in rats or mice. Spermatogenic disturbance induced by DEHP is significantly prevented by treatment with antioxidant vitamins in the rat. The vitamin has the ability to regenerate vitamin $\mathrm{E}$. This means that any function vitamin $\mathrm{E}$ has within the body can also be linked back to vitamin C. It is involved in scavenging free radicals generated during cellular metabolism. It may protect lipids and lipoproteins in cellular membranes against oxidative damage caused by toxic free radicals at early stage. Bashandy \& Alwasel [49] showed that vitamin $\mathrm{C}$ had a protective effect caused by oxidative stress via its antioxidative property, reducing the lipid peroxidation and normalizing glutathione level with improved alterations in biochemical markers.

Vitamin $\mathrm{C}$ is the best known preventive antioxidant against reproductive toxicity of pesticides [50]. It inhibits oxidation by an effect on calcium metabolism [51] and catalysis of the reduction of hydrogen peroxide which protect biological membranes from oxidative degradation. DEHP administration decreases glutathione, vitamin $\mathrm{C}$ and $\mathrm{E}$ in rat testes [52,53], therefore administration of vitamins $\mathrm{C}$ and $\mathrm{E}$ is effective in prevention and treatment of DEHPinduced aspermatogenesis [54].

Vitamin $\mathrm{C}$ is known to protect spermatogenesis and it plays a major role in semen integrity and fertility both in men and animals [45], increases testosterone levels [55] and prevents sperm agglutination. It is an important chain-breaking antioxidant, contributing up to 65 percent of the total antioxidant capacity of seminal plasma found intracellulary and extracellulary [37]. Shrilatha \& Muralidhara [56] reported protective effect of vitamin $\mathrm{C}$ on testicular oxidative stress, sperm oxidative stress and genotoxic effects in mice.

In conclusion, our results indicate that exposure of nursing mothers during lactation to DEHP can cause harmful effects on the testes of their lactating offspring males, as reflected by decreased body weight, orchidosomatic index and retardation in postnatal development of the testes of their offspring males. This study showed also that addition of honey to the drinking water or injection of vitamin $\mathrm{C}$ into nursing mothers during lactation ameliorated these effects as reflected by the noticeable enhancement in the studied parameters. So, it is advised to give honey and/or vitamin $\mathrm{C}$ to those exposed to household pollutants such as DEHP especially babies.

\section{References}

[1] Agency for Toxic Substances and Disease Registry (ATSDR) Atlanta, CA: Division of Toxicology; 2002. Toxicological profile for di(2ethylhexyl)phthalate (DEHP) Atlanta, GA: Division of Toxicology (2002)

[2] J.A. Tickner, T. Schettler, T. Guidotti, M. McCally, M. Rossi, Health risks posed by use of di-2-ethylhexyl phthalate (DEHP) in PVC medical devices: a critical review. Am. J. Ind. Med . 39 (2001) 100-111

[3] M. Rossi, M. Muehlberger, Neonatal exposure to DEHP (di-2-ethylhexyl phthalate) and opportunities for prevention in Europe. Health Care Without Harm, Centre national d'information indépendante sur les dechets, CNIID, Pari. Toxicol. 32 (2000) 453-473

[4] R. Yanagisawa, H. Takano, K. Inoue, E. Koike, K. Sadakane, T. Ichinose, Effects of maternal exposure to di-(2-ethylhexyl) phthalate during fetal and/or neonatal periods on atopic dermatitis in male offspring. Environmental Health Perspectives 116 (2008) 1136-1141

[5] P.C. Huang, C.J. Tien, Y.M. Sun, C.Y. Hsieh, C.C. Lee, Occurrence of phthalates in sediment and biota: relationship to aquatic factors and the biota-sediment accumulation factor. Chemosphere 73 (2008) 539-44

[6] B. Kolarik, K. Naydenov, M. Larsson, C.G. Bornehag, J. Sundell, The association between phthalates in dust and allergic diseases among Bulgarian children, Environ. Health Perspect. 116 (2011) 98

[7] B.H. Kim, H.S. Park, H.J. Kim, G.T. Kim, I.S. Chang, J. Lee, N.T. Phung, Enrichment of microbial community generating electricity using 
a fuel cell type electrochemical cell. Appl. Microbiol. Biotechnol. 63 (2004) 672-681

[8] M. Matsumoto, M. Hirata-koizumi, M. Ema, Potential adverse effects of phthalic acid esters on human health: A review of recent studies on reproduction. Regul. Toxicol. Pharmacol. 50 (2008) 37-49

[9] G. Latini, C. De Felice, G. Presta, A. Del Vecchio, I. Paris, F. Ruggieri, P. Mazzeo, In utero exposure to di-(2-ethylhexyl)phthalate and duration of human pregnancy. Environ. Health Perspect. 111 (2003) 1783-1785

[10] K.M. Main, I.M. Smith, N.E. Skakkebæk, A possible role for reproductive hormones in newborn boys: progressive hypogonadism without the postnatal testosterone peak. J. Clin. Endocrinol. Metab. 85 (2006) 4905-4907

[11] G.K. Mortensen, K.M. Main, A.M. Andersson, H. Leffers, N.E. Skakkebæk, Determination of phthalate monoesters in human breast milk, consumer milk and infant formula by tandem mass spectrometry (LC/MS/MS). Anal. Bioanal. Chem. 382 (2005) 1084-1092

[12] L.K. Sorensen, Determination of phthalates in milk and milk products by liquid chromatography/tandem mass spectrometry. Rapid Commun. Mass Spectro. 20 (2006) 1135-1143

[13] S.D. Holladay, R.J. Smialowicz, Development of the murine and human immune system: differential effects of immunotoxicants depend on time of exposure. Environ. Health Perspect. 108 (2000) 463-473

[14] A.M. Calafat, A.R. Slakman, M.J. Silva, A.R. Herbert, L.L. Needham, Automated solid phase extraction and quantitative analysis of human milk for 13 phthalate metabolites. J. Chromatog. Anal. Technol. Biomed. Life 805 (2004) 49-56

[15] A. Mohamed, T. Sainath, G. Dahl, B. Ramabhadran, G. Hinton, M. Picheny, Deep Belief Networks using Discriminative Features for Phone Recognition. In Proc. ICASSP 11 (2011) 5060-5063

[16] A.M.A. Zaid, J.M. Bonasera, S.V. Beer, First report of Enterobacter decay caused by Enterobacter cloacae in New York. Plant Dis. 95 (2011) 1581

[17] F. Koc, N. Kalay, I. Ardic, K. Ozbek, A. Celik, K. Ceyhan, H. Kadi, M. Karayakali, B. Kolarik, K. Naydenov, M. Larsson, C.G. Bornehag, J. Sundell, The association between phthalates in dust and allergic diseases among Bulgarian children, Environ. Health Perspect. 116 (2008) 98

[18] K.A. Kassim, R. Hamir, K. C. Kok, Modification and stabilization of Malaysian cohesive soils with lime. Geotechnical Engineering, J. South East Asian Geotech. Soc. 36 (2010) 123-132

[19] M., Victor, A.H. Ropper, Diseases of nervous System due to nutritional deficiency. In
Adams and Victor's principles of Neurology. New York, McGraw-Hill Publishing Company, (2001) 1218-1223

[20] S.J. Padayatty, M. Levine, Vitamin C and coronary microcirculation. Circulation 103 (2003) E117

[21] Z.N. Öztürk, V. Talame', M. Deyholos, C.B. Michalowski, D.W. Galbraith, N. Gozukirmizi, R. Tuberosa, H.J. Bohnert, Monitoring largescale changes in transcript abundance in droughtand saltstressed barley. Plant Mol. Biol. 48 (2001) 551-573

[22] R.B. Drury, E.A. Wallingto, Carletons Histological Technique.oxford University Press (1980) 520

[23] J. Erenpreisa, T. Freivalds, H. Roach, R. Alston, Apoptotic cell nuclei favour aggregation and fluorescence quenching of DNA dyes. Histochem. Cell Biol. 108 (1997) 67-75

[24] X.F. Song, Y.J. Deng, D.Y. Zhang, X. Liu, S.D. Wu, G.H. Wei, [Di(2-ethylhexyl) phthalate affects the testes and leydig cells of neonatal KM mice. 15 (2009) 195-199

[25] J.D. Park, S.S. Habeebu, C.D. Klaassen Testicular toxicity of di-(2-ethylhexyl) phthalate in young Sprague-Dawley rats. Toxicol. 171 (2002) 105-115

[26] I. Rusyn, J.M. Peters, M.L. Cunnigham, Modes of action and species-specific effects of di-(2ethylhexyl)phthalate in the liver. Crit. Rev. Toxicol. 36 (2006) 459-479

[27] N.B. Thuy, K. Tanimoto,;N. Tanaka, K. Harada, K. Iimura, Effect of Open Gap in Coastal Forest on Tsunami Run-up - Investigations by Experiment and Numerical Simulation, Ocean Engineering 36 (2009) 1258-1269

[28] Z. Zhu, T. Zheng, C.G. Lee, R.J. Homer, J.A. Elias, Tetracyclinecontrolled transcriptional regulation systems: advances and application in transgenic animal modeling. Semin. Cell Dev. Biol. 13 (2009) 121-128

[29] R.W. Moore, T.A. Rudy, T.M. Lin, K. Ko, R.E. Peterson, Abnormalities of sexual development in male rats with in utero and lactational exposure to the antiandrogenic plasticizer $\operatorname{Di}(2-$ ethylhexyl) phthalate. Environ Health Perspect. 109 (2001) 229-237

[30] K. Boekelheide, Cracking the nut. Toxicol. Sci. 81 (2004) 1-2

[31] L.E. Jr Gray, J. Ostby, J. Furr, M. Price, D.N. Veeramachaneni, L. Parks, Perinatal exposure to the phthalates DEHP, BBP, and DINP, but not DEP, DMP, or DOTP, alters sexual differentiation of the male rat. Toxicol Sci. 8 (2005) 350365

[32] J.N. Cammack, R.D. White, D. Gordon, J. Gass, L. Hecker, D. Conine, U.S. Bruen, M. Friedman, C. Echols, T.Y. Yeh, D.M. Wilson, Evaluation of reproductive development following intravenous and oral exposure to DEHP in male neonatal rats. 
Int. J. Toxicol. 22 (2003) 159-174

[33] B.T. Akingbemi, R. Ge, G.R. Klinefelter, B.R. Zirkin, M.P. Hardy, Phthalate-induced Leydig cell hyperplasia is associated with multiple endocrine disturbances. Proc. Natl. Acad. Sci. USA 101 (2004) 775-780

[34] J. Borch, O. Ladefoged, U. Hass, A.M. Vinggaard, Steroidogenesis in fetal male rats is reduced by DEHP and DINP, but endocrine effects of DEHP are not modulated by DEHA in fetal, prepubertal and adult male rats. Reprod. Toxicol. 18(2004) 53-61

[35] K.L. Howdeshell, V.S. Wilson, J. Furr, C.R. Lambright, C.V. Rider, C.R. Blystone, A.K. Hotchkiss, L.E.Jr Gray, A mixture of five phthalate esters inhibits fetal testicular testosterone production in the sprague-dawley rat in a cumulative, dose-additive manner. Toxicol. Sci. 105 (2008) 153-165

[36] S.H. Swan, K.M. Main, F. Liu, Decrease in anogenital distance among male infants with prenatal phthalate exposure. Environ. Health Perspect. 113 (2008) 1056-1061

[37] J.D. Meeker, H. Hu, D.E. Cantonwine, H. Lamadrid-Figueroa, A.M. Calafat, A.S. Ettinger, M. Hernandez-Avila, R. Loch-Caruso, M.M. Téllez-Rojo, Urinary phthalate metabolites in relation to preterm birth in Mexico City. Environ. Health Perspect 117 (2009) 1587-1592

[38] Y. Miura, M. Naito, M. Ablake, H. Terayama, S. Q. Yi, N. Qu, L.X. Cheng, S. Suna, F. Jitsunari, M. Itoh, Short-term effects of di-(2-ethylhexyl) phthalate on testes, liver, kidneys and pancreas in mice. Asian J. Andro. 19 (2007) 199-205

[39] N.J. Barlow, P.M. Foster, Pathogenesis of male reproductive tract lesions from gestation through adulthood following in utero exposure to di(nbutyl) phthalate. Toxicol. Pathol. 31 (2003) $397-$ 410

[40] C.E. Talsness, A.J.M. Andrade, S.N. Kuriyama, J.A. Taylor, F.S. Vom Saal, Components of plastic: Experimental studies in animals and relevance for human health. Philosophical Transactions of the Royal Society B: Biological Sciences 364 (2009) 2079-2096

[41] H. M. Scott, G.R. Hutchison, M.S. Jobling, C. McKinnell, A.J. Drake, R.M. Sharpe, Relationship between androgen action in the "Male programming window," fetal sertoli cell number, and adult testis size in the rat. Endocrinology 149 (2008) 5280-5287

[42] J.C. Corton, P.J. Lapinskas, Peroxisome Proliferator-Activated Receptors: Mediators of Phthalate Ester-Induced Effects in the Male Reproductive Tract? Toxicol. Sci. 83 (2005) 4 17

[43] K.W. Seo, K.B. Kim, Y.J. Kim, J.Y. Choi, K.T. Lee, K.S. Choi, Comparison of oxidative stress and changes of xenobiotic metabolizing enzymes induced by phthalates in rats. Food Chem. Toxicol. 42 (2004) $107-114$

[44] C. Perez, S. Nickovic, G. Pejanovic, J.M. Baldasano, E.O Zsoy, Interactive dust-radiation modeling: A step to improve weather forecasts, J. Geophys. Res. in press.

[45] A. Agarwal, R.A. Saleh, M.A. Bedaiwy, Role of reactive oxygen species in the pathophysiology of human reproduction. Fertil. Steril. 79 (2005) 829-843

[46] E. Miccadei, P. Paron, T. Piacentini, The SW escarpment of the Montagna del Morrone (Abruzzi, Central Italy). geomorphology of a faulted-generated mountain front. Geografia Fisica e Dinamica Quaternaria 7 (2008) 55-87

[47] M. Mahaneem, A.S. Siti, M.K. Yatiban, J. Hasnan, Effects of Malaysian honey on the male reproductive system in rats. Malayasian J. Med. Sci. 14 (2007) 114

[48] H.M. Abdulghani, S.I. Karim, F. Irfan, Emergency contraception: Knowledge and attitudes of family planning physicians of a teaching hospital, Karachi, Pakistan J. Health Popul. Nutr. 27 (2009) 339-334

[49] S.A. Bashandy, S.H. AlWasel, Carbon Tetrachloride-induced Hepatotoxicity and Nephrotoxicity in Rats: Protective Role of Vitamin C. J. Pharmacol, Toxicol. 6 (2011) 283292

[50] M. Uzunhisarcikli, Y. Kalender, K. Dirican, S. Kalender, A. Ogutcu, F. Buyukkomurcu, Acute, subacute and subchronic administration of methyl parathion- induced testicular damage in male rats and protective role of vitamins $\mathrm{C}$ and E. Pestic. Biochem. Physiol. 87 (2007) 115-122

[51] S.J. Stohs, D. Bagchi, E. Hassoun, M. Bagchi, Oxidative mechanisms in the toxicity of chromium and cadmium ions. J. Environ. Pathol. Toxicol. Oncol. 20 (2001) 77-88

[52] N. Ishihara, Y. Fujita, T. Oka, K. Mihara, Regulation of mitochondrial. 63 (2006) 53-44

[53] N. Serbecic, S.C. Beutelspacher, Vitamins inhibit oxidant-induced apoptosis of corneal endothelial cells. Jpn. J. Ophthalmol. 49 (2005) 355-362

[54] A. Avilés-Quevedo,,Cultivo de peces marinos. In: Estado de salud de la acuacultura, 2000, pp. 1-16. DGIAINP, SEMARNAT, Mexico.

[55] H. Sonmez, E. Tuncay, C. Gokceoglu, H. Nefeslioglu, Matriks icinde blok iceren kayaclarin deformasyon modulunun saptanabilmesine yonelik fotoanaliz destekli yaklasimlarin gelistirilmesi”.TUBITAK Proje No: 102 Y033 (in Turkish) 15 (2005) 155-159

[56] B. Shrilatha, B. Muralidhara, Occurrence of oxidative impairments, response of antioxidant defences and associated biochemical perturbations in male reproductive milieu in the streptozotocin-diabetic rat. Int. J. Androl. 30 (2007) 508-518 
الملخص العربى

الدور الوقائي لبعض المنتجات الطبيعية ضد التسمم المستحدث في خصية ذرية الفئران بواسطة الفثالات

$$
\begin{aligned}
& \text { لطفي زكريا حبق، عبد العزيز خضر 1، حكمت لطفي الجمال1، ريم اشتيوي مسعود2 }
\end{aligned}
$$

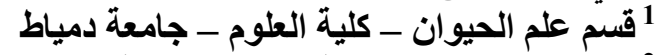

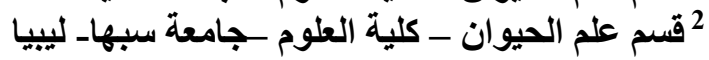

تعتبر الفتالات من أكثر الملوثات البينية انتثارا بسبب استخدامها كإضافات لعدد كبير من المنتجات البلاستيكية وكذلك

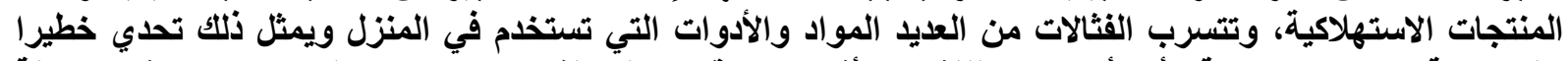

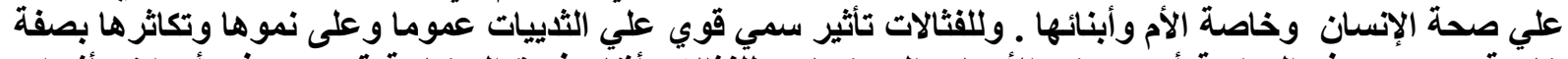

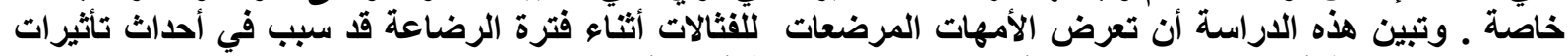

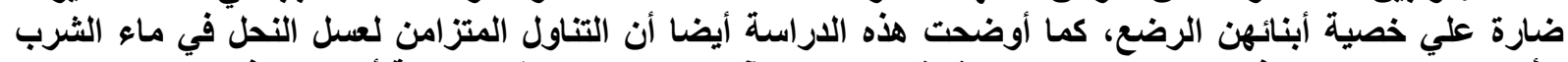

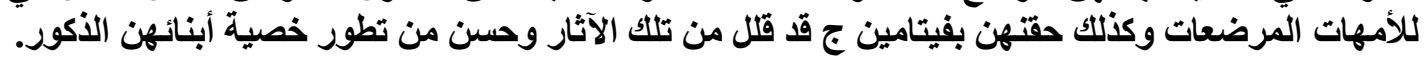

